\title{
Micropropagation of rhubarb with special reference to weaning stage and subsequent growth
}

\author{
Carola Lassus and Irma Voipio
}

LASsus, C. \& VoIPIO, I. 1994. Micropropagation of rhubarb with special reference to weaning stage and subsequent growth. Agricultural Science in Finland 3: 189-194. (Department of Plant Production, P.O.B. 27, FIN-00014 University of Helsinki, Finland.)

\begin{abstract}
Micropropagation of rhubarb (Rheum rhabarbarum L.) on MS medium with sucrose $20 \mathrm{~g} / \mathrm{l}$ and agar $8 \mathrm{~g} / \mathrm{l}$, supplemented with benzylaminopurine (BAP) $1 \mathrm{mg} / \mathrm{l}$ and indolebutyric acid (IBA) $1 \mathrm{mg} / \mathrm{l}$ for initiation and multiplication, was studied with cv. Victoria and clone AF. With clone AF, the effects of rooting method (direct rooting, direct rooting with Floramon $\mathrm{A}$ or in vitro rooting) and propagule size (height $1.5-2.0,2.1-5.0$ or $5.1-10.0 \mathrm{~cm}$ ) on weaning survival and plant size were examined. Further growth was recorded over a 3-year period in field studies.

The medium gave a multiplication rate of $3.2 / 4$ weeks for clone AF. For cv. Victoria, the medium did not seem suitable because of high occurrence of callus and vitrification. The multiplication rate of $\mathrm{cv}$. Victoria was, however, increased from 2.8 to $5.4 / 4$ weeks by using propagules from non-sprouting instead of sprouting buds. The weaning survival of clone AF averaged $86 \%$. Rooting method did not affect either weaning survival or plant size. Propagule size affected plant size, but not weaning survival or further growth in the field.
\end{abstract}

Key words: direct rooting, in vitro rooting, growth in field studies, propagule size

\section{Introduction}

Rhubarb is usually propagated vegetatively since seed propagation results in undesired variation among progeny. Conventional propagation by crown division gives, at best, a 4- to 6-fold multiplication rate every 2 years. By using singlebud division, ca. 240 plants/mother plant can be produced during a 6-month season (CASE 1970, NORMAN 1978). Viruses are, however, transmitted through these propagation methods. WALKEY

\footnotetext{
Abbreviations: MS $=$ MURASHIGE and SKOOG (1962), BAP $=$ benzylaminopurine, $\mathrm{IBA}=$ indolebutyric acid, $\mathrm{NAA}=$ naphthaleneacetic acid
}

(1968) succeeded in eliminating viruses from rhubarb through in vitro culture of meristem tips. The method has been further developed for rapid multiplication (Roggemans and Claes 1979, WALKeY and MatTHEWs 1979, PIERIK et al. 1989, CAmara Machado et al. 1990, Rumpunen 1990). In theory, based on the average multiplication rate of $2.8 / 2$ weeks obtained by WALKEY and MATTHEWs (1979), it is possible to produce over a million rhubarb plants within 7 months from a single meristem tip initiated in vitro.

In micropropagation, direct rooting is recommended whenever possible because of considerably lower costs compared with in vitro rooting. Furthermore, roots formed in vitro are easily dam- 
aged during planting (CONNER and THOMAS 1981, Debergh and Maene 1981). To maximize weaning survival, it appears that the propagule must exceed a certain minimum size (CONNER and THOMAS 1981). The leaves formed in vitro are found to act mainly as storage organs (WARDLE et al. 1983) and, after transferring to soil, enough nutrient reserves should be present to supply the plant's requirements until total autotrophy is reached (CAPELLADES et al. 1990).

The aim of this study was to investigate micropropagation of rhubarb, especially the effects of direct rooting and propagule size on weaning survival and ex vitro growth. To observe the after effects, further growth was examined in a field trial over 3 years.

\section{Material and methods}

Clone AF was used as plant material in Experiments 1 and 4, and cv. Victoria in Experiments 2 and 3. In Experiment 1, the shoot multiplication rate was calculated from 139 propagules and in Experiment 2 from 70 propagules in the third subculture. In Experiment 1, the buds available were mostly non-sprouting and in Experiment 2 mostly sprouting. In Experiment 3, the multiplication rates of propagules from sprouting and nonsprouting buds (13 and 24 propagules, respectively) were compared in the first subculture.

In Experiment 4, where the shoots of clone AF from Experiment 1 were used, the effects of rooting method (in vitro rooting, direct rooting and direct rooting with Floramon A treatment $(0.1 \%$ NAA)) and propagule size (small, medium and large) on weaning survival and plant size ex vitro were studied. The propagule size categories, measured as shoot height on the basis of the longest petiole, were $1.5-2.0 \mathrm{~cm}$ (small), $2.1-5.0 \mathrm{~cm}$ (medium) and 5.1-10.0 cm (large). In Experiment 4, the factor combinations were arranged in triplicate (with 10 plants per replicate) according to a randomized block design.

Experiments 1 and 2 began with in vitro initiation in May and Experiment 3 in October 1989. The excised buds from parental crowns were washed in tap water, disinfected in $3.5 \%$ sodium hypochlorite for $10 \mathrm{~min}$ and rinsed 3 times in sterilized, deionized water. The excised shoot tips were $1-2 \mathrm{~mm}$ in diameter. The basal medium consisted of MS medium with sucrose $20 \mathrm{~g} / \mathrm{l}$ and Bacto agar (Difco) $8 \mathrm{~g} / \mathrm{l}$, with $\mathrm{pH}$ adjusted to 5.5 . For initiation and multiplication, the media were supplemented with BAP (Sigma) $1 \mathrm{mg} / \mathrm{l}$ and IBA (Merck) $1 \mathrm{mg} / \mathrm{l}$. No growth regulator was added to the rooting medium. All media were autoclaved for $15 \mathrm{~min}$ at $121^{\circ} \mathrm{C}$.

The explants were initially grown in culture tubes containing $10 \mathrm{ml}$ medium and, after 4-6 weeks, were transferred to $100 \mathrm{ml}$ Erlenmeyer flasks containing $50 \mathrm{ml}$ medium. The multiplication stage was started after an initiation period of 8 weeks (Experiments 1 and 2) or 6 weeks (Experiment 3 ). The temperature in the growth chamber was $22-27^{\circ} \mathrm{C}$, except during the multiplication stage in Experiments 1 and 2, when it occasionally rose to $31^{\circ} \mathrm{C}$. Daylength was $16 \mathrm{~h}$ and irradiance ca. $6 \mathrm{~W} \mathrm{~m}^{-2}$ (PAR) (lamp type 'Kirkas de Luxe', Airam).

In Experiment 4, the shoots for in vitro rooting were kept for one week on the rooting medium. At transplanting, $32 \%$ of the shoots had $1-10$ visible roots $0.1-5.0 \mathrm{~cm}$ in length. The shoots for direct rooting were harvested directly from the multiplication medium, and half of the shoots were treated with Floramon A. For transplanting, all shoots were transferred to a glasshouse and placed in a plastic tent which was shaded during sunny days. The growth substrate was a 2:1 mixture of fertilized peat (Vapo B2) and vermiculite (grain size $2-3 \mathrm{~mm}$ ). The mean air temperature in the glasshouse was $22^{\circ} \mathrm{C}$. Natural light conditions prevailed at the start of the growing period (September), and after 5 weeks supplementary light was provided for $16 \mathrm{~h} /$ day (lamp type HPI-T, Philips). After 18 days, the relative humidity was reduced from $100 \%$ to ca. $70 \%$ over a period of one week by gradually opening the tent. At the same time, the irrigation water was supplemented with gradually increasing amounts $(0.05-0.2 \%)$ of fertilizer. During the first 3 weeks, the fertilizer was '4Superex' (17N-4P-25K, Kekkilä), and thereafter '5-Superex' (11N-4P-25K, Kekkilä). 
Plants rooted in vitro and those rooted directly without Floramon A (all size categories: 2 × 3 x $8=48$ plants) were potted and overwintered in a glasshouse until May 1990 when they were planted randomly in an outdoor nursery at a density of $30 \mathrm{~cm}$ x $30 \mathrm{~cm}$. On 29 May 1991, the plants were transplanted in a field at a density of $100 \mathrm{~cm} \mathrm{x}$ $125 \mathrm{~cm}$. Conventional growing techniques were adopted. The first crop was harvested in 1992. The field experiment was arranged in quadruplicate (with two plants per replicate) according to a randomized block design.

In Experiments 1 to 3, the number of shoots/ propagule was counted after 4 weeks. Callus occurrence was recorded in Experiments 1 and 2, and vitrification in Experiments 1 to 3. The multiplication data from Experiment 3 were analyzed by Mann-Whitney's U-test. In Experiment 4, the proportion of surviving plantlets, the length of the longest petiole, the number of leaves, and fresh and dry weights of the foliage were recorded. In the field trial, the number of leaves, and the length and the weight of the longest petioles at harvest were recorded. A logistic regression model and analysis of variance were applied to the survival results. The other data were analyzed using analysis of variance and the $\mathrm{S}-\mathrm{N}-\mathrm{K}$ test for mean separation.

\section{Results}

In Experiment 1 with clone AF, the multiplication rate was 3.2/4 weeks, and in Experiment 2 with cv. Victoria 2.1/4 weeks. During initiation, callus occurrence was $30 \%$ for clone AF and $80 \%$ for cv. Victoria, and during the multiplication stage 78 and $100 \%$, respectively. No vitrification was found in clone AF, but in cv. Victoria, $15 \%$ of the shoot clusters were vitrified. In Experiment 3 with cv. Victoria, the multiplication rate was higher $(\mathrm{p} \leq 0.05)$ for propagules from non-sprouting buds $(5.4 / 4$ weeks, variation interval $[1,17])$ than from sprouting buds $(2.8 / 4$ weeks, $[1,8])$. In both treatments, $35 \%$ of the shoot clusters were vitrified.

In Experiment 4, no significant differences in weaning survival or plant size caused by different rooting methods were found (Tables 1 and 2). Propagule size did not affect weaning survival significantly, but plant size was affected (Table 1). After a 7-week growing period, plants from large propagules had a dry and fresh weight 4.5-fold higher than those from small propagules (Table 2).

Except for one of the in vitro rooted plant of the category "small" that died during the nursery stage, no further plants died later in the experiment. In the field trial, no after effects of the

Table 1. Effect of rooting method and propagule size on weaning survival and plant size after a 4-week growing period in Experiment 4 with clone AF.

\begin{tabular}{lccc}
\hline Treatment & $\begin{array}{c}\text { Weaning } \\
\text { survival, \% }\end{array}$ & $\begin{array}{c}\text { Petiole } \\
\text { length, cm }\end{array}$ & $\begin{array}{c}\text { Number } \\
\text { of leaves }\end{array}$ \\
\hline $\begin{array}{l}\text { Rooting method: } \\
\text { direct rooting } \\
\text { direct rooting + }\end{array}$ & $86.7 \mathrm{a}$ & $6.9 \mathrm{a}$ & $4.9 \mathrm{a}$ \\
$\quad \begin{array}{l}\text { Floramon A } \\
\text { in vitro rooting }\end{array}$ & $83.3 \mathrm{a}$ & $5.6 \mathrm{a}$ & $4.3 \mathrm{a}$ \\
$\begin{array}{l}\text { Propagule size: } \\
\text { small }\end{array}$ & $88.9 \mathrm{a}$ & $8.0 \mathrm{a}$ & $4.7 \mathrm{a}$ \\
$\quad$ medium & $80.0 \mathrm{a}$ & & $4.1 \mathrm{~b}$ \\
$\quad$ large & $87.8 \mathrm{a}$ & $4.2 \mathrm{c}$ & $4.4 \mathrm{~b}$ \\
\hline
\end{tabular}

Values for rooting method and propagule size separately followed by the same letter are not significantly different at $\mathrm{P}=0.05$. 
Table 2. Effect of rooting method and propagule size on plant size after a 7-week growing period in Experiment 4 with clone AF.

\begin{tabular}{lcccc}
\hline & $\begin{array}{c}\text { Petiole } \\
\text { length, cm }\end{array}$ & $\begin{array}{c}\text { Number } \\
\text { of leaves }\end{array}$ & $\begin{array}{c}\text { Foliage fresh } \\
\text { weight, } \mathrm{g}\end{array}$ & $\begin{array}{c}\text { Foliage dry } \\
\text { weight, } \mathrm{g}\end{array}$ \\
\hline $\begin{array}{l}\text { Rooting method: } \\
\text { direct rooting } \\
\text { direct rooting + }\end{array}$ & $14.0 \mathrm{a}$ & $7.4 \mathrm{a}$ & $16.6 \mathrm{a}$ & $0.88 \mathrm{a}$ \\
$\begin{array}{l}\text { Floramon A } \\
\text { in vitro rooting }\end{array}$ & $12.4 \mathrm{a}$ & $6.6 \mathrm{a}$ & $11.9 \mathrm{a}$ & $0.68 \mathrm{a}$ \\
$\begin{array}{l}\text { Propagule size: } \\
\text { small }\end{array}$ & $14.8 \mathrm{a}$ & $7.1 \mathrm{a}$ & $19.0 \mathrm{a}$ & $0.96 \mathrm{a}$ \\
medium & $11.2 \mathrm{c}$ & $6.3 \mathrm{~b}$ & $6.0 \mathrm{c}$ & $0.31 \mathrm{c}$ \\
large & $13.3 \mathrm{~b}$ & $7.2 \mathrm{a}$ & $13.6 \mathrm{~b}$ & $0.79 \mathrm{~b}$ \\
\hline
\end{tabular}

Values for rooting method and propagule size separately followed by the same letter are not significantly different at $\mathrm{P}=0.05$.

Table 3. Effect of propagule size on the further development and yield of clone AF during 1990-1992.

\begin{tabular}{|c|c|c|c|c|c|c|c|}
\hline \multirow{2}{*}{$\begin{array}{l}\text { Year and } \\
\text { date }\end{array}$} & \multirow[t]{2}{*}{ Variable } & \multicolumn{6}{|c|}{ Propagule size } \\
\hline & & small & $\mathrm{CV} \%$ & medium & $\mathrm{CV} \%$ & large & CV\% \\
\hline \multicolumn{8}{|l|}{1990} \\
\hline 21 June & Number of leaves & 3.3 & 39 & 3.1 & 32 & 3.3 & 24 \\
\hline 8 Aug. & & 13.2 & 40 & 15.3 & 35 & 15.6 & 39 \\
\hline \multicolumn{8}{|l|}{1991} \\
\hline \multirow[t]{2}{*}{23 May } & $\begin{array}{l}\text { Number of leaves } \\
\text { Longest }\end{array}$ & 24.2 & 16 & 26.8 & 23 & 26.7 & 23 \\
\hline & petiole, $\mathrm{cm}$ & 24.4 & 15 & 24.4 & 20 & 24.8 & 13 \\
\hline \multicolumn{8}{|l|}{$1992 x)$} \\
\hline \multirow[t]{3}{*}{22 May } & Petiole & & & & & & \\
\hline & - length, cm & 34 & 9 & 34 & 5 & 35 & 4 \\
\hline & - weight, g & 100 & 18 & 108 & 10 & 100 & 14 \\
\hline \multirow[t]{3}{*}{4 June } & Petiole & & & & & & \\
\hline & - length, cm & 45 & 9 & 45 & 5 & 46 & 5 \\
\hline & - weight, g & 121 & 13 & 122 & 14 & 128 & 15 \\
\hline
\end{tabular}

No significant differences at $\mathrm{P}=0.05$.

$\mathrm{CV}=$ coefficient of variation for respective variable in $\mathrm{CV} \%$.

x) Five largest leaves per plant were harvested on both dates.

rooting method were found (data not presented). The differences between propagule size categories were not significant (Table 3). Variation in the measured growth parameters between individuals was considerable. Among the 47 surviving plants, no morphologically aberrant ones were found.

\section{Discussion}

The nutrient medium gave an acceptable multiplication rate for clone AF. However, for cv. Victoria, the medium did not seem optimal for micropropagation because of vitrification and the low multiplication rate in Experiment 2. The dif- 
ference in multiplication rate might be due to genotype since cv. Victoria propagates slowly in vivo (WALKeY and MatTHEws 1979). In Experiment 3 , the multiplication rate of $\mathrm{cv}$. Victoria was increased by using propagules from nonsprouting instead of sprouting buds. The results of Experiments 2 and 3 are, however, not directly comparable since the time of year for bud excision can affect their hormone and carbohydrate levels (GEORGE and SHERrington 1984).

The high callus occurrence especially in cv. Victoria indicates a too high auxin level, which agrees with the findings of CAMARA MACHADO et al. (1990) with cv. Holsteiner Blut. The occasionally high incubation temperature in the multiplication stage possibly enhanced callus formation and reduced the multiplication rate since the efficiency of cytokinins is found to decrease as the temperature rises, but that of auxins to increase (GEORGE and SHERRINGTON 1984). Further, less callus formation and a higher multiplication rate have been obtained in rhubarb by using glucose instead of sucrose as carbohydrate source (RUMPUNEN 1990).

In a preliminary test with rhubarb, direct rooted shoots survived well but grew more slowly than in vitro rooted ones (RUMPUNEN 1990). In our study with clone $\mathrm{AF}$, direct and in vitro rooting gave nearly identical results. The small size of the propagules was no obstacle to good survival, but 7 weeks after transplanting, plants from small propagules were clearly inferior in weight to plants from larger propagules. They also had fewer leaves but, at the nursery stage, the number of leaves was almost the same in all propagule categories.

The risk of genetic changes is minimal if shoot tip explants and optimum nutrient medium are used (GEORge and Sherrington 1984). In our field trial, no morphologically aberrant plants were observed but, between individuals, the variations in number of leaves and petiole length were considerable. These variations could be due to environmental factors. Somaclonal variation cannot be excluded, but since the variations decreased with time, they would most likely be of epigenetic character, possibly associated with virus elimination.

In conclusion, micropropagated shoots of clone AF can be rooted directly, and even shoots 1.5 to $2 \mathrm{~cm}$ in height do root and develop well. For cv. Victoria, a suitable initiation and multiplication medium should be designed.

\section{References}

Camara Machado, M. L. da, Camara Machado, A. da, Hanzer, V., Kalthoff, B., Weiss, H., MattanoVICH, D., Regner, F. \& KATINGeR, H. 1990. In-vitro Vermehrung von Rhabarber (Rheum rhaponticum). Mitteilungen Klosterneuburg, Rebe und Wein, Obstbau und Früchteverwertung 40: 84-87.

Capellades, M., Vanderschaeghe, A., Lemeur, R. \& DEBERGH, P. 1990. How important is photosynthesis in micropropagation? Current Plant Science and Biotechnology in Agriculture 8: 29-38. Dordrecht.

CASE, M. W. 1970. Production and propagation of virus free stocks of rhubarb. Ministry of Agriculture, Fisheries and Food. Experimental Husbandry Farms and Experimental Horticultural Stations. Annual Report 11: 133-134.

Conner, A. J. \& Thomas, M. B. 1981. Re-establishing plantlets from tissue culture: a review. Combined Proceedings of the International Plant Propagators' Society $31: 342-257$.
Debergh, P. C. \& Maene, L. J. 1981. A scheme for commercial propagation of ornamental plants by tissue culture. Scientia Horticulturae 14: 335-345.

George, E. F. \& Sherrington, P. D. 1984. Plant propagation by tissue culture. Handbook and directory of commercial laboratories. 709 p. Basingstoke.

Murashige, T. \& Skoog, F. 1962. A revised medium for rapid growth and bioassays with tobacco cultures. Physiologia Plantarum 15: 473-497.

NORMAN, B. 1978. Forced rhubarb revival urged by Stockbridge House EHS. Grower 89: 904, 906.

PieriK, R. L. M., BANGA, M. \& JAnson, J. 1989. Vegetatieve vermeerdering van rabarber in kweekbuizen. [Vegetative propagation of rhubarb in growing tubes.] Prophyta 43: 13-14.

Roggemans, J. \& Claes, M.-C. 1979. Rapid clonal propagation by in vitro culture of shoot-tips. Scientia Horticulturae 11: 241-246.

RUMPUNEN, K. 1990. Mikroförökning av rabarber. Sum- 
mary: Micropropagation of rhubarb. Sveriges Lantbruksuniversitet. Avdelningen för Hortikulturell Växtförädling. Balsgård - Verksamhetsberättelse 1988-1989: 126-133.

WAlkeY, D. G. A. 1968. The production of virus-free rhubarb by apical tip culture. The Journal of Horticultural Science 43: 283-287.

- \& MATthews, K. A. 1979. Rapid clonal propagation of rhubarb (Rheum rhaponticum L.) from meristem-tips in tissue culture. Plant Science Letters 14: 287-290.

Wardle, K., Dalsou, V., Simpkins, I. \& Short, K. C. 1983. Re-distribution of rubidium in plants of Chrysanthemum morifolium Ram. cv. Snowdon derived from tissue cultures and transferred to soil. Annals of Botany $51: 261-264$.

Manuscript received October 1993

\title{
SELOSTUS
}

\section{Raparperin mikrolisäys, versojen juurtuminen karaisuvaiheessa ja myöhempi kasvu}

\author{
Carola Lassus ja Irma Voipio
}

Helsingin yliopisto

Tutkimuksessa haluttiin selvittää, onnistuuko mikrolisätyn raparperin suora juurrutus turve-vermikuliittialustalle, onko eri pituisten versojen juurtumisessa eroja ja ilmeneekö myöhemmässä kasvussa juurrutustavasta tai lisäyksessä käytetyn verson koosta johtuvia eroja.

Lajiketta Victoria ja kloonia AF mikrolisättiin juurakon silmujen kärkisolukoista Murashigen ja Skoogin kehittämällä alustalla (MS-alusta), joka sisälsi $20 \mathrm{mg} / \mathrm{l}$ sakkaroosia ja $8 \mathrm{mg} / \mathrm{l}$ agaria. Aloitus- ja monistusvaiheissa alustaan lisättiin $1 \mathrm{mg}$ bentsyyliaminopuriinia ja $1 \mathrm{mg}$ indolivoihappoa litraa kohti. Juurrutusmenetelmän ja verson koon vaikutusta juurtumiseen ja myöhempään kasvuun tutkittiin käyttäen kloonia AF. Tämän kokeen taimien jatkokasvua avomaalla seurattiin kolmen vuoden ajan.
Klooni AF tuotti keskimäärin 3,2 versoa 4 viikossa. Lajikkeella Victoria tulos oli heikompi, ja kallusmuodostusta ja vesisoluisuutta esiintyi runsaasti. Victoria lajikkeen versojen tuotto parantui, kun lisäys tapahtui levossa olevista silmuista. Suoraan turve-vermikuliittialustalle istutetut kloonin AF versot juurtuivat yhtä hyvin $(87 \%)$ kuin ne, joiden istutusta edelsi juurrutusvaihe MS-alustalla $(89 \%)$. Pienet versot (pisimmän lehden korkeus 1,5 $2 \mathrm{~cm})$ juurtuivat lähes yhtä hyvin kuin keskikokoiset $(2,1$ $-5 \mathrm{~cm})$ tai suuret $(5,1-10 \mathrm{~cm})$. Suurimmista versoista kehittyneet taimet olivat karaisuvaiheen päättyessä kookkaimmat. Taimisto- ja peltoviljelyvaiheissa ei havaittu juurrutustavasta tai verson koosta johtuvia eroja. 